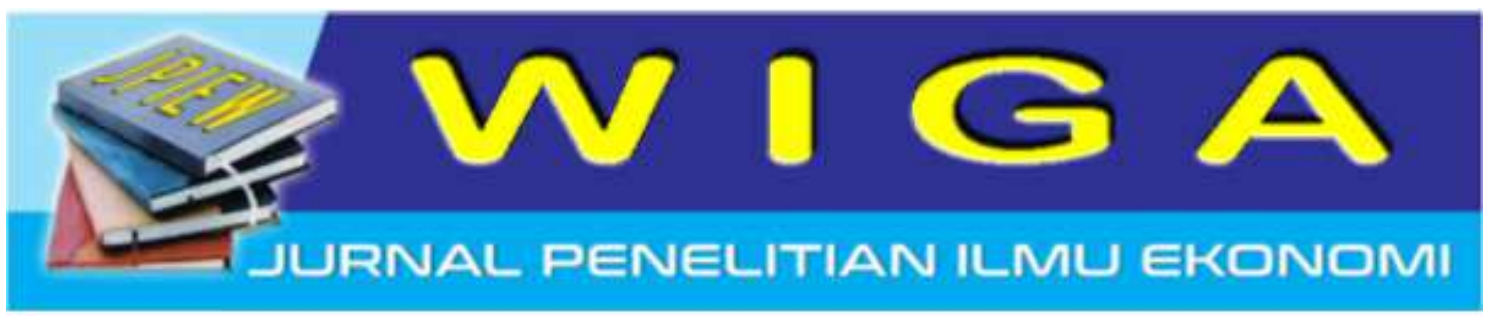

\title{
IMPLEMENTASI LEAN SIX SIGMA DALAM PENENTUAN PRIORITAS PERBAIKAN KUALITAS PELAYANAN PADARUMAH SAKIT DI KABUPATEN LUMAJANG
}

\author{
Mohammad Ato'illah', ${ }^{1)}$ Hartono $^{2)}$ \\ STIE Widya Gama Lumajang \\ atok_wiga@yahoo.com
}

\begin{abstract}
ABSTRAK. Penelitian bertujuan menentukan prioritas perbaikan kualitas pelayanan rumah sakit berdasarkan persepsi, harapan dan tingkat kepentingan pelanggan dengan menggunakan pendekatan lean six sigma. Hasil penelitian diharapkan dapat memberikan kontribusi bagi pengelola rumah sakit dalam memberikan pelayanan terbaik bagi masyarakat. Penelitian ini menentukan prioritas perbaikan kualitas pelayanan rumah sakit berdasarkan dimensi kualitas pelayanan yang terdiri dari (1) keterwujudan (tangible), (2) kehandalan (reliability), (3) daya tanggap (reponsiveness), (4) jaminan (assurance) dan (5) empati (emphaty). Penelitian ini merupakan penelitian deskriptif kualitatif dimaksudkan untuk menganalisis tanggapan responden atas kualitas pelayanan rumah sakit berdasarkan persepsi, harapan dan kepentingan yang akan digunakan untuk menentukan prioritas perbaikan kualitas pelayanan rumah sakit. Responden penelitian sebanyak 240 orang pengguna jasa pada empat rumah sakit di Kabupaten Lumajang. Teknik analisis data menggunakan pendekatan lean six sigma dengan terlebih dulu menguji instrument penelitian dengan uji validitas dan reliabilitas. Hasil penelitian terdapat perbedaan urutan prioritas perbaikan kualitas layanan pada empat rumah sakit. Prioritas perbaikan pada rumah sakit Dr. Haryoto adalah kemampuan dan kecekatan dalam menghadapi keluhan pasien, pada rumah sakit Bhayangkara adalah ketepatan waktu buka loket pelayanan, pada rumah sakit Wijaya Kusuma adalah kelengkapan peralatan pemeriksaan, dan pada rumah sakit Islam adalah kemampuan petugas menjelaskan hasil pemeriksaan.
\end{abstract}

Kata kunci : lean six sigma; persepsi; harapan; kepentingan; kualitas pelayanan.

ABSTRACT. The study aims to determine the priority of quality improvement of hospital service based on perception, expectations and importance of customers by using lean six sigma approach. The results of the study are expected to contribute to hospital management in providing the best service for the community. This research determines the priority of service quality improvement of hospital based on service quality dimension consisting of (1) tangible, (2) reliability, (3) reponsiveness, (4) assurance and (5) emphaty. This study is a qualitative descriptive research intended to analyze the responses of respondents on the quality of hospital services based on perception, expectations and importance will be used to determine the priority of improving the quality of hospital services. Research respondents were 240 service users in four hospitals in Lumajang district. Data analysis technique using lean six sigma approach by first testing the research instrument with validity and reliability test. The results of the study there are differences in the order of priority of service quality improvement at four hospitals. Priority improvement in $d r$ Haryoto hospital is the ability and dexterity in dealing with patient complaints, at the Bhayangkara hospital is the timeliness of open counter service, at Wijaya Kusuma hospital is completeness of examination equipment, and Islam hospital is the ability of the officer to explain the results of the examination.

Keywords : lean six sigma; perception, expectations; importance, service quality 


\section{PENDAHULUAN}

Kualitas layanan yang optimal harus selalu dilakukan dibidang apapun karena tanpa kualitas layanan yang baik maka dapat menimbulkan kekecewaan konsumen, pelanggan maupun masyarakat, pada akhirnya akan berujung pada loyalitas mereka. Strategi yang tepat dibutuhkan untuk menemukan apa yang seharusnya menjadi prioritas perbaikan agar kualitas layanan dapat diberikan dengan optimal. Salah satu cara yang dapat dipergunakan adalah lean six sigma. Sejak diperkenalkan oleh Motorola pada tahun 1800 an, six sigma banyak diadopsi oleh berbagai perusahaan untuk meningkatkan kualitas produk yang dihasilkan. Six Sigma merupakan alat untuk memperbaiki kualitas produk dengan mereduksi tingkat kecacatan produk melalui 5 (lima) tahapan yaitu define (identifikasi masalah), measure (pengukuran performance kualitas), analyze (melakukan analisa terhadap penyebab kecacatan), improvement (melakukan usaha perbaikan untuk meningkatkan kualitas) dan controll atau pengendalian (Ratnaningtyas, Surendro, 2013 dalam Hana Catur Wahyuni dkk, 2015:21). Prinsip Lean Six Sigma adalah segala aktifitas yang menyebabkan critical to quality pada konsumen dan hal-hal yang menyebabkan waste delay yang lama pada setiap proses merupakan peluang/kesempatan yang sangat baik untuk melakukan perbaikan dan peningkatan dalam halbiaya, kualitas, modal, dan lead time (George, 2002 dalam Hana Catur Wahyuni dkk, 2015:23).

Penerapan konsep Lean Six Sigma dapat dilakukan pada industri jasa maupun manufaktur. Salah satu industri jasa yang menarik untuk diterapkan konsep Lean Six Sigma ini adalah jasa pelayanan kesehatan melalui rumah sakit. Dengan seakin meningkatnya kebutuhan masyarakat atas kesehatan dan meningkatnya persaingan maka rumah sakit juga dituntut untuk bis amemberikan pelayanan yang prima. Oleh karea itu upaya yang sungguh-sungguh untuk menyiapkan sumber daya kesehatan perlu dimaksimalkan di semua level organisasi di rumah sakit. Saat ini kesehatan sudah dianggap sebagai suatu kebutuhan masyarakat untuk hidup sehat. Perkembangan layanan kesehatan yang cukup pesat saat ini, menuntut pengelola rumah sakit mengelola usahanya dengan baik. Kondisi ini menciptakan persaingan yang semakin tajam, membuat rumah sakit yang mampu mengelola layanan kesehatannya dengan baik akan bisa bertahan bahkan berkembang, tetapi bagi yang tidak mampu mengelola dengan baik maka akan semakin terpuruk yang pada akhirnya akan kalah dalam persaingan yang semakin ketat. Salah satu untuk dapat memenangkan ketatnya tingkat persaingan adalah meraih kepercayaan masyarakat dengan memberikan kepuasan kepada masyarakat atau pelanggan. Kepuasan pelanggan akan terpenuhi jika mereka mendapatkan pelayanan yang berkualitas dan dengan merasa puas maka mereka akan menunjukkan loyalitasnya.

Kepuasan pelanggan adalah perasaan senang atau kecewa seorang yang timbul karena membandingkan kinerja yang dipersepsikan produk atau hasil terhadap ekspetasi mereka. Jika kinerja gagal memenuhi ekspektasi, pelanggan akan tidak puas. Jika kinerja sesuai dengan ekpektasi maka pelanggan akan puas. Jika kinerja melebihi ekpektasi, pelanggan akan sangat puas atau senang (Kotler \& Keller, 2002:139). Sedangkan menurut Thamrin \& Francis, (2012:45) kepuasan pelanggan adalah hasil yang dirasakan pembeli dari kinerja perusahaan yang memenuhi harapan mereka. Pelanggan puas bila harapan mereka dipenuhi dan senang atau harapan mereka dilebihi. Pelanggan yang puas akan setia lebih lama, membeli lebih banyak, kurang sensitif pada harga dan memberikan komentar baik tentang perusahaan. Sedangkan menurut Richard.F.Gerson kepuasan pelanggan adalah persepsi pelanggan bahwa harapannya telah terpenuhi atau terlampaui. Kepuasan pelanggan bermakna perbandingan antara apa yang diharapkan konsumen dengan apa yang dirasakan konsumen ketika menggunakan produk tersebut. Bila konsumen merasakan performa produk sama atau melebihi ekspetasinya, berarti mereka puas. Sebaliknya jika perfoma produk kurang dari ekspetasinya, berarti mereka puas. Alma (2005:135).

Pengertian kualitas pelayanan menurut Kotler \& Keller (2002:143), totalitas fitur dan karakteristik produk atau jasa yang bergantung pada kemampuannya untuk 
memuaskan kebutuhan yang dinyatakan atau tersirat. Dan menurut Thamrin \& Francis (2012:44), kualitas adalah keseluruhan ciri dan karakteristik suatu barang atau jasa yang berpengaruh pada kemampuannya untuk memuaskan kebutuhan yang dinyatakan maupun yang tersirat. Kualitas pelayanan jasa dapat dievaluasi dengan menggunakan dimensi servive quality (SERVQUAL) yang dikembangkan oleh Zeithaml, Berry dan Parasuraman (2002:21), terdiri dari 5 (lima) atribut yaitu : (1) bukti langsung (tangibles), (2) kehandalan (reliability), (3) daya tanggap (responsiveness), (4) jaminan (assurance) dan (5) empati (empathy).

Penelitian pada rumah sakit di Kabupaten Lumajang karena perkembangannya yang cukup pesat dalam memberikan layanan kesehatan pada masyarakat. Di Kabupaten Lumajang saat ini terdapat 4 (empat) rumah sakit besar yaitu Rumah Sakit Umum Daerah Dr. Haryoto, Rumah Sakit Wijaya Kusuma, Rumah Sakit Bhayangkara dan yang terbaru adalah Rumah Sakit Islam Lumajang. Keempat rumah sakit besar di Lumajang ini saling bersaing dalam memberikan pelayanan kesehatan sebaikbaiknya kepada masyaarakt Lumajang. Masalah dirumuskan sebagai berikut:

1. Bagaimana implementasi lean six sigma dalam penentuan prioritas perbaikan kualitas pelayanan berdasarkan persepsi, harapan dan kepentingan masyarakat pada masing-masing rumah sakit di Kabupaten Lumajang ?

2. Apa saja prioritas perbaikan prioritas perbaikan kualitas pelayanan berdasarkan persepsi, harapan dan kepentingan masyarakat pada seluruh rumah sakit di Kabupaten Lumajang ?

Berdasarkan latar belakang masalah dan perumusan masalah maka tujuan penelitian ini adalah :

1. Untuk penentuan prioritas perbaikan kualitas pelayanan berdasarkan persepsi, harapan dan kepentingan masyarakat pada masing-masing rumah sakit di Kabupaten Lumajang.

2. Untuk penentuan prioritas perbaikan kualitas pelayanan berdasarkan persepsi, harapan dan kepentingan masyarakat pada seluruh rumah sakit di Kabupaten Lumajang.

\section{METODE PENELITIAN}

Jenis penelitian ini adalah penelitian deskriptif kualitatif dimana peneliti bermaksud menganalisis data dengan cara mendeskripsikan atau mengambarkan data yang telah terkumpul sebagaimana adanya tanpa bermaksud membuat kesimpulan yang berlaku untuk umum atau generalisasi”. (Sugiyono, 2009:206). Penelitian ini bermaksud untuk menganalisis tanggapan responden atas kualitas pelayanan rumah sakit berdasarkan persepsi, harapan dan kepentingan masyarakatyang pada akhirnya kan digunakan untuk menentukan prioritas perbaikan kualitas pelayanan rumah sakit. Berdasarkan sifatnya, penelitian ini bersifat eksploratif karena pengujian lebih lanjut atas suatu penelitian diperlukan maka penelitian tersebut bersifat eksploratif.

Penelitian ini dilakukan terhadap masyarakat pengguna jasa rumah sakit di Kabupaten Lumajang. Adapun masyarakat yang dijadikan obyek dalam penelitian ini adalah kategori pelanggan yaitu datang lebih dari 1 (satu) kali dalam memanfaatkan layanan jasa kesehatan di rumah sakit di Kabupaten Lumajang. Pelanggan akan diberikan kuesioner untuk menjaring pendapat mereka atas kualitas layanan rumah sakit berdasarkan kepentingan, harapan dan persepsi pelanggan.Adapun rumah sakit yang menjadi obyek penelitian adalah 4 (empat) rumah sakit besar di Kabupaten Lumajang, yaitu :

1. Rumah Sakit Umum Daerah Dr. Haryoto Lumajang

2. Rumah Sakit Bhayangkara Lumajang

3. Rumah Sakit Wijaya Kusuma Lumajang

4. Rumah Sakit Islam Lumajang

Menurut sumbernya, data yang diperoleh untuk dianalisis dalam penelitian ini adalah data internal dan ekternal yaitu data yang diperoleh dari pihak bank dan nasabah, sedangkan jenis datanya adalah primer karena data dikumpulkan langsung dari sumbernya yaitu masyarakat/pelanggan pengguna jasa rumah sakit. Data primer ini berupa hasil kuesioner untuk menjaring pendapat responden atas kualitas pelayanan rumah sakit di Kabupaten Lumajang. Data yang digunakan penelitian ini berupa berskala ordinal yaitu data yang dinyatakan dalam bentuk kategori tetapi posisi data tidak sama derajatnya karena dinyatakan dalam skala peringkat. 
Teknik pengumpulan data adalah dengan menggunakan kuesioner atau daftar pertanyaan yang dikirimkan kepada responden, baik secara langsung maupun dengan bantuan pihak rumah sakit. Untuk penyebaran kuesioner sebagai bahan penelitian diberikan kepada masyarakat / pelanggan pengguna jasa rumah sakit dengan jumlah responden sebanyak 240 responden, yang diambil dari masing-masing rumah sakit sebanyak 60 responden.. Tujuannya untuk menjaring pendapat responden tentang kualitas pelayanan rumah sakit berdasarkan kepentingan, harapan dan persepsi mereka.Pengukuran data dilakukan dengan memberi skor pada tiap-tiap jawaban dari butir pertanyaan dari kuesioner. Pemberian skor dalam penelitian ini berdasarkan skala likert. Adapun bentuk skala likert menurut Sugiyono (2008:93) sebagai berikut:

1. Sangat setuju/ selalu/ sangat positif (SS/ SL) diberi skor 5

2. Setuju/ sering/ positif (ST/ SR) diberi skor 4

3. Ragu- ragu/ kadang-kadang. Netral (RG/ KS) diberi skor 3
4. Tidak setuju/ hampir tdak pernah/ negative (TS/ TP) diberi skor 2

5. Sangat tidak setuju/ tidak pernah (STS/ S) diberi skor 1

Populasi dalam penelitian ini adalah seluruh masyarakat pengguna jasa rumah sakit di Kabupaten Lumajang. Metode penentuan ukuran sampel yang digunakan adalah metode yang dikembangkan oleh Roscoe dalam bukunya Research Methods For Business (1982:253) seperti yang dikutip dalam (Sugiyono, 2009:129), yaitu jumlah anggota sampel minimal 10 (sepuluh) kali dari jumlah variabel yang diteliti. Jumlah variabel yang digunakan untuk mengukur kualitas pelayanan ini terdiri dari 5 (lima) variabel. Maka ukuran sampel yang diambil minimal $=10 \times 5$ variabel $=50$ anggota sampel untuk setiap rumah sakit. Jumlah sampel ditingkatkan menjadi 12 x 5 variabel $=60$ sampel. Jumlah rumah sakit yang diteliti sebanyak 4 (empat) rumah sakit, jadi jumlah sampel keseluruhan adalah $60 \times 4=$ 240 responden.

Adapun variabel, instrument dan skala pengukuran yang digunakan untuk menjaring persepsi, harapan dan kepentingan responden disajikan dalam tabel sebagai berikut:

Tabel 1. Matriks Variabel, Instrumen dan SkalaPengukuran

\begin{tabular}{|c|c|c|c|c|}
\hline No. & Variabel & Indikator & Instrumen & Skala \\
\hline 1. & $\begin{array}{l}\text { Bentuk Fisik } \\
\text { (Tangible) }\end{array}$ & $\begin{array}{l}\text { Daya tarik fasilitas, } \\
\text { perlengkapan dan material } \\
\text { yang digunakan pihak } \\
\text { rumah sakit, serta } \\
\text { penampilan karyawan }\end{array}$ & $\begin{array}{l}\text { a. Kebersihan dan kenyamanan ruang } \\
\text { tunggu } \\
\text { b. Jumlah loket pembayaran yang } \\
\text { memadai } \\
\text { c. Tata letak ruangan yang indha dan } \\
\text { rapi } \\
\text { d. Tempat parkir yang rapi dan aman } \\
\text { e. Ketersediaan dan kelengkapan obat } \\
\text { di apotik } \\
\text { f. Kelengkapan peralatan pemeriksaan } \\
\text { g. Kerapian petugas pelayanan }\end{array}$ & Ordinal \\
\hline
\end{tabular}

$\begin{array}{ll}\text { 2. } & \text { Keandalan } \\ & \text { (Realiability) }\end{array}$
(Realiability)

\begin{abstract}
Kemampuan pihak rumah sakit untuk memberikan layanan yang akurat pada pelanggan sejak pertama kali tanpa membuat kesalahan apapun dan menyampaikan jasanya sesuai dengan waktu yang disepakati.
\end{abstract}

a. Ketepatan waktu buka loket pelayanan

b. Lamanya waktu pelayanan petugas loket

c. Lamanya waktu pelayanan petugas pemeriksaan

d. Lamanya waktu pelayanan petugas apotik

e. Besarnya biaya pengobatan

f. Petugas melakukan pemeriksaan sesuai prosedur 
Ato'illah, Implementasi Lean Six

\begin{tabular}{|c|c|c|c|c|}
\hline & (Responsiveness) & $\begin{array}{l}\text { kemampuan para } \\
\text { karyawan rumah sakit } \\
\text { untuk membantu } \\
\text { pelanggan dan merespon } \\
\text { permintaan mereka serta } \\
\text { menginformasikan kapan } \\
\text { jasa akan diberikan dan } \\
\text { kemudian memberikan } \\
\text { jasa secara cepat. }\end{array}$ & $\begin{array}{l}\text { dalam menanggapi keluhan } \\
\text { pelanggan } \\
\text { b. Kemampuan dan kecekatan petugas } \\
\text { dalam menjawab pertanyaan } \\
\text { pelanggan } \\
\text { c. Kemampuan dan kecekatan petugas } \\
\text { menjelaskan hasil pemeriksaan } \\
\text { kepada pelanggan }\end{array}$ & \\
\hline 4. & $\begin{array}{l}\text { Jaminan } \\
\text { (Assurance) }\end{array}$ & $\begin{array}{l}\text { Perilaku karyawan rumah } \\
\text { sakit agar mampu } \\
\text { menumbuhkan } \\
\text { kepercayaan pelanggan } \\
\text { kepada rumah sakit, } \\
\text { menciptakan rasa aman } \\
\text { pagi pelanggan. }\end{array}$ & $\begin{array}{l}\text { a. Keramahan petugas } \\
\text { b. Ketrampilan dan keahlian petugas } \\
\text { c. Kecekatan petugas memeriksa pasien } \\
\text { d. Kejelasan petugas informasi biaya } \\
\text { pemeriksaan } \\
\text { e. Kejelasan informasi tindak lanjut } \\
\text { hasil pemeriksaan }\end{array}$ & Ordinal \\
\hline 5. & Empati (Emphaty) & $\begin{array}{l}\text { Rumah sakit memahami } \\
\text { masalah para pelanggan } \\
\text { dan bertindak demi } \\
\text { kepentingan pelanggan } \\
\text { serta memberikan } \\
\text { perhatian personal kepada } \\
\text { pelanggan. }\end{array}$ & $\begin{array}{l}\text { a. Kesabaran dan keramahan petugas } \\
\text { dalam melayani pelanggan } \\
\text { b. Kesabaran dan keramahan petugas } \\
\text { dalam melakukan pemeriksaan } \\
\text { c. Kesabaran dan keramahan petugas } \\
\text { dalam mendengarkan keluhan } \\
\text { pelanggan } \\
\text { d. Pelanggan mudah menyampaikan } \\
\text { keluhan/saran kepada pihak rumah } \\
\text { sakit }\end{array}$ & Ordinal \\
\hline
\end{tabular}

Sumber data : Parasuraman, Berry, Zeithaml, 1990 dalam Hana Catur Wahyuni dkk (2015:33).

\section{Teknik Analisis Data}

Data diperoleh dari kuesioner yang harus diisi responden, oleh karena itu akan dilakukan pengujian instrumen penelitian yaitu uji validitas dan reliabilitas. Selanjutkan dilakukan langkah-langkah untuk menentukan prioritas perbaikan layanan bank berdasarkan perhitungan gap dan penentuan bobot sebagai berikut:

a. Identifikasi Gap Tanpa Bobot

Perhitungan nilai gap tanpa bobot yaitu dengan mencari selisih antara nilai harapan dengan nilai persepsi masyarakat. Nilai gap yang dimaksud adalah nilai gap rata-rata yang diperoleh dari selisih nilai rata-rata harapan masyarakat dengan nilai ratarata persepsi masyarakat atas dimensi kualitas layanan rumah sakit.

b. Identifikasi Gap Terbobot

Perhitungan gap terbobot dimana bobot diperoleh dari rasio tingkat kepentingan masing-masing pernyataan terhadap jumlah total tingkat kepentingan, sedangkan nilai gap diperoleh dari perhitungan nilai gap tanpa bobot. Gap terbobot merupakan hasil perkalian antara bobot dan nilai gap

c. Prioritas Perbaikan Kualitas Layanan Rumah Sakit

Berdasarkan perhitungan nilai gap terbobot maka dapat disusun prioritas perbaikan. Dimana prioritas perbaikan akan didasarkan pada pengurutan nilai gap terbobot terbesar sampai gap terbobot terkecil.

\section{HASIL DAN PEMBAHASAN Hasil Penelitian}

Responden dalam penelitian ini adalah masyarakat Lumajangyang pernah merasakan pelayanan di rumah sakit di Kabupaten Lumajang. Jumlah sampel dalam penelitian ini sebesar 60 responden untuk setiap rumah sakit, dimana terdapat 4 (empat rumah sakit) di Lumajang yang diteliti.Jadi terdapat 240 sampel dari rumah sakit di Lumajang, yaitu (1) Rumah Sakit Umum Daerah Dr. Haryoto Lumajang, (2) Rumah Sakit Bhayangkara Lumajang, (3) Rumah Sakit Wijaya Kusuma Lumajang, dan (4) Rumah Sakit Islam Lumajang. Deskripsi 
responden disajikan dalam tabel sebagai berikut:

Tabel 2. Deskripsi Responden Menurut Jenis Kelamin

\begin{tabular}{cccc}
\hline No. & $\begin{array}{c}\text { Jenis } \\
\text { Kelamin }\end{array}$ & Jumlah & $\%$ \\
\hline 1. & Laki - Laki & 128 & $53,33 \%$ \\
\hline 2. & Perempuan & 112 & $46,66 \%$ \\
\hline & Jumlah & 240 & $100 \%$ \\
\hline
\end{tabular}

Sumber data : Hasil Kuesioner Penelitian, 2017.

Tabel 3.Deskripsi Responden Menurut Jenis Pekerjaan

\begin{tabular}{clcc}
\hline No. & Jenis Pekerjaan & Jml & $\%$ \\
\hline 1. & Pegawai & 42 & $17,50 \%$ \\
\hline 2. & Karyawan Swasta & 54 & $22,50 \%$ \\
\hline 3. & Wiraswasta & 44 & $18,33 \%$ \\
\hline 4. & Mahasiswa/Pelajar & 50 & $20,83 \%$ \\
\hline 5. & Ibu RT & 34 & $14,17 \%$ \\
\hline 6. & Lainnya & 16 & $6,67 \%$ \\
\hline & Jumlah & 240 & $100 \%$ \\
\hline
\end{tabular}

Sumber data : Hasil Kuesioner Penelitian, 2017.

Responden dijaring pendapatnya atas kualitas layanan pada 4 (empat) rumah sakit di Lumajang untuk mengisi kuesioner berdasarkan persepsi, harapan dan kepentingan mereka. Hasil pengisian kuesioner dari 240 responden direkapitulasi dalam nilai rata-rata pada tabel sebagai berikut:

Tabel 4.Deskripsi Tanggapan Responden

\begin{tabular}{clccc}
\hline No & $\begin{array}{c}\text { Rumah } \\
\text { Sakit }\end{array}$ & $\begin{array}{c}\text { Persep } \\
\text { si }\end{array}$ & Harapan & $\begin{array}{c}\text { Kepenting } \\
\text { an }\end{array}$ \\
\hline 1. & $\begin{array}{l}\text { RSUD Dr. } \\
\text { Haryoto } \\
\end{array}$ & & & \\
& Lumajang & 2,98 & 3,91 & 3,89 \\
\hline 2. & $\begin{array}{l}\text { RS } \\
\text { Bhayangka }\end{array}$ & 3,36 & 3,86 & 3,67 \\
\hline
\end{tabular}

\begin{tabular}{|c|c|c|c|c|}
\hline & $\begin{array}{l}\text { ra } \\
\text { Lumajang }\end{array}$ & & & \\
\hline 3. & $\begin{array}{l}\text { RS Wijaya } \\
\text { Kusuma } \\
\text { Lumajang }\end{array}$ & 3,31 & 3,51 & 3,52 \\
\hline 4. & $\begin{array}{l}\text { RS Islam } \\
\text { Lumajang }\end{array}$ & 3,19 & 3,22 & 3,21 \\
\hline
\end{tabular}

Sumber data : Hasil Kuesioner Penelitian, 2017.

Instrumen yang digunakan untuk menjaring persepsi, harapan dan kepentingan responden ini menggunakan kuesioner, oleh karena itu atas kuesioner itu dilakukan uji validitas dan reliabilitas.Hasil pengujian validitas kuesioner atas 25 pernyataan tentang kualitas pelayanan di 4 (empat) rumah sakit di Lumajang menunjukkan bahwa semua item pernyataan pada masingmasing variabel tersebut $r$ hitung $>0,3$ dengan tingkat signifikan di bawah 5\%, maka dapat disimpulkan bahwa kuesioner yang digunakan untuk menggali data adalah valid sehingga dapat menggali data atau informasi yang diperlukan. Sedangkan hasil pengujian reliabilitas kuesioner menunjukkan bahwa semua item pernyataan pada masingmasing variabel mempunyai nilai Cronbach's Alpha dengan range nilai masuk kategori sangat reliabel. Jadi dapat disimpulkan semua konsep pengukur masing-masing variabel dari kuesioner yang digunakan dalam penelitian ini merupakan kuesioner yang handal.

Selanjutnya dilakukan proses analisis data menggunakan pendekatan lean six sigma terhadap kualitas layanan rumah sakit. Dari perhitungan gap tidak berbobot yang dilanjutkan dengan perhitungan gap terbobot maka diperoleh hasil urutan prioritas perbaikan kualitas layanan rumah sakit sebagai berikut:

Tabel 5.TigaPrioritas Utama Perbaikan Kualitas Layanan Rumah Sakit

\begin{tabular}{|c|c|c|}
\hline Variabel & Pernyataan & Prioritas \\
\hline \multirow{3}{*}{$\begin{array}{l}\text { RSUD Dr. Haryoto } \\
\text { Lumajang }\end{array}$} & Kemampuan dan kecekatan hadapi & 1 \\
\hline & Keramahan petugas & 2 \\
\hline & Ketrampilan dan keahlian petugas & 3 \\
\hline \multirow{2}{*}{$\begin{array}{l}\text { RS Bhayangkara } \\
\text { Lumajang }\end{array}$} & Ketepatan waktu buka loket pelayanan & 1 \\
\hline & Kesabaran petugas mendengarkan & 2 \\
\hline
\end{tabular}


Ato'illah, Implementasi Lean Six

\begin{tabular}{lll}
\hline & keluhan & \\
\cline { 2 - 3 } & Lamanya waktu pelayanan petugas loket & 3 \\
\hline RS Wijaya Kusuma & Kelengkapan peralatan pemeriksaan & 1 \\
\cline { 2 - 3 } Lumajang & Besarnya biaya pengobatan & 2 \\
\cline { 2 - 3 } & $\begin{array}{l}\text { Kejelasan informasi tindak lanjut hasil } \\
\text { pemeriksaan }\end{array}$ & 3 \\
\hline RS Islam Lumajang & $\begin{array}{l}\text { Kemampuan petugas jelaskan hasil } \\
\text { pemeriksaan }\end{array}$ & 1 \\
\cline { 2 - 3 } & $\begin{array}{l}\text { Kejelasan petugas informasi biaya } \\
\text { pemeriksaan }\end{array}$ & 2 \\
\hline & $\begin{array}{l}\text { Lamanya waktu pelayanan petugas } \\
\text { apotik }\end{array}$ & 3 \\
\hline
\end{tabular}

Sumber Data : Hasil kuesioner diolah, 2017.

\section{Pembahasan Hasil Penelitian \\ Prioritas Perbaikan Kualitas Layanan di RSUD Dr. Haryoto Lumajang}

Berdasarkan hasil kuesioner yang disebarkan tentang kualitas layanan rumah sakit berdasarkan persepsi, harapan dan kepentingan masyarakat di Lumajang maka diperoleh urutan jenis layanan yang kemudian diambil prioritas yang harus diperbaiki agar Rumah Sakit Umum Daerah Dr. Haryoto Lumajang dapat nmemberikan layanan yang optimal. Prioritas perbaikan kualitas layanan pada RSUD Dr. Haryoto Lumajang terdiri dari : (1) kemampuan dan kecekatan hadapi keluhan pasien, (2) keramahan petugas, dan (3) ketrampilan dan keahlian petugas.

Kemampuan dan kecekatan petugas dalam menghadapi keluhan pasien, diketahui menjadi gap tertinggi antara persepsi, harapan dan kepentingan masyarakat.Rumah Sakit Umum Daerah Dr. Haryoto Lumajang merupakan satu-satunya rumah sakit milik pemerintah Kabupaten Lumajang dan terbesar di kabupaten Lumajang. Banyak masyarakat yang menggunakan jasa rumah sakit ini karena memang jenis layanan nya yang cukup lengkap dibandingkan rumah sakit lainnya di Lumajang. Namun demikian anggapan masyarakat bahwa kemampuan dan kecekatan hadapi keluhan pasien menjadi hal utama yang harus menjadi perhatian rumah sakit ini.Hal ini bisa terjadi mengingat karena fasilitasnya yang lengkap maka banyak masyarakat yang berdatangan ke rumah sakit ini baik untuk rawat inap maupun rawat jalan.Banyaknya masyarakat yang dating untuk berobat inilah yang nampaknya kurang berimbang dengan petugas yang idsediakan sehingga masyarakat menganggap bahwa rumah sakit ini kurang mampu dan kurang cekatan dalam menghadapi keluhan pasien saat menggunakna jasa layanan rumah sakit ini.

Keramahan petugas juga menjadi prioritas kedua untuk jenis layanan rumah sakit yang harus diprioritaskan untuk diperbaiki.Masyarakat yang menggunakan jasa rumah sakit pada umumnya dating untuk berobat dan dalam kondisi kesehatan yang tidak optimal. Bagi mereka petugas di rumah sakit ini kurang ramah dalam memberikan pelayanan kesehatan. Bagi sebagian besar orang yang sehat, keramahan petugas dalam memberikan pelayanan saja menjadi hal yang utama, apalagi bagi oarng dengan kondisi sakit terkadang pelayanan yang tidak ramah itu akan sangat mengganggu kenyaman mereka dalam berobat. Demikian juga ketrampilan dna keahlian petugas yang merupakan urutan prioritas perbaikan kualitas layanan ketiga yang dikehendaki masyarakat sesuai dengan persepsi, harapan dan kepentingan mereka. Masyarakat sangat menghendaki mendapatkan pelayanan kesehatan dari tenaga kesehatan yang trampil dan cekatan.Mereka menganggap bahwa petugas kesehatan di rumah sakit ini kurang trampil dan kurang cekatan dalam memberikan layanan kesehatan bagi masyarakat.

Atas kondisi ini, maka disarankan kepada pihak Rumah Sakit Umum Daerah Dr. Haryoto Lumajang untuk melakukan perbaikan sesuai urutan prioritas yang dikehendaki masyarakat terutama 3 (tiga) prioritas yang menimbulkan kesenjangan atau gap yang cukup tinggi berdasarkan persepsi, harapan dan kepentingan masyarakat, yaitu dengan meningkatkan 
kemampuan dan kecekatan dalam menghadapi keluhan pasien, meletakkan petugas-petugas kesehatan yang ramah dalam melayani masyarakat yang sedang berobat, dan meningkatkan ketrampilan dan keahlian petugas pelayanan kesehatan. Namun demikian berdasarkan urutan prioritas tersebut, dapat diketahui bahwa rumah sakit ini memiliki keunggulan tentang yang memberikan nilai gap terkecil yang menunjukkan bahwa masyarakat menganggap rumah sakit ini memiliki tata letak ruangan yang sangat membantu masyarakat dalam berobat. Demikian juga dengan kelengkapan peralatan pemeriksaan memberikan kepuasan tersendiri bagi masyarakat karena mereka tidak harus berobat ke luar kota untuk mendapatkan pelayanan kesehatan yang lengkap peralatannya.

\section{Prioritas Perbaikan Kualitas Layanan di RS Bhayangkara Lumajang}

Berdasarkan hasil kuesioner yang disebarkan tentang kualitas layanan rumah sakit berdasarkan persepsi, harapan dan kepentingan masyarakat di Lumajang maka diperoleh urutan jenis layanan yang kemudian diambil prioritas yang harus diperbaiki agar Rumah Sakit Bhayangkara Lumajang dapat memberikan layanan yang optimal. Prioritas perbaikan kualitas layanan pada Rumah Sakit Bhayangkara Lumajang terdiri dari : (1) ketepatan waktu buka loket pelayanan, (2) kesabaran petugas mendengarkan keluhan pasien, dan (3) lamanya waktu pelayanan petugas loket.

Ketepatan waktu membuka loket pelayanan, diketahui menjadi gap tertinggi bagi masyarakat yang menggunakan jasa layanan rumah sakit Bhayangkara di Lumajang ini.Masyarakat menganggap bahwa loket pelayanan di rumah sakit ini tidak tepat waktu dalam membuka layannnya. Hal ini sebenarnya bukan masalah yang yang seharusnya tidak menjadi keluhan masyarakat, namun bagi masyarakat dengan kondisi yang sangat membutuhkan memang mereka akan sangat mengharapkan dan berkepentingan untuk mendapatkan ketepatan waktu pada bagian loket pelayanan. Kesabaran petugas dalam mendengarkan atau menanggapi keluhan pasien juga menjadi keluhan atau gap yang tinggi dimana masyarakat menganggap bahwa petugas rumah sakit ini kurang sabar dalam mendengarkan keluhan pasien atas kesehatannya.Lamanya waktu pelayanan petugas loket pelayan juga menjadi keluhan yang juga harus mendapatkan prioritas perbaikan.

Atas kondisi ini, maka disarankan kepada pihak Rumah Sakit Bhayangkara Lumajang untuk melakukan perbaikan sesuai urutan prioritas yang dikehendaki masyarakat terutama 3 (tiga) prioritas yang menimbulkan kesenjangan atau gap yang cukup tinggi berdasarkan persepsi, harapan dan kepentingan masyarakat, yaitu dengan memastikan loket pelayanan buka tepat waktu, memberikan waktu yang lebih bagi petugas untuk dapat mendengarkan keluhan pasien atas penyakit yang dideritanya, dan mempercepat waktu pelayanan di bagian loket. Kondisi tentang ketidaktepatan waktu membuka loket pelayanan dan lamanya pelayanan di loket seharusnya bukan menjadi hal yang sulit untuk diperbaiki. Jika rumah sakit segera melakukan perbaikan pada bagian ini maka kesenjangan ketidakpuasan masyarakat dapat segera diatasi.Namun demikian berdasarkan urutan prioritas tersebut, dapat diketahui bahwa rumah sakit ini memiliki keunggulan yaitu kemampuan petugas menjelaskan hasil pemeriksaan memiliki gap terkecil sehingga dapat diartikan bahwa masyarakat puas dengan kemampuan petugas di rumah sakit ini dalam menjelaskan hasil pemeriksaan atas kesehatan mereka.

\section{Prioritas Perbaikan Kualitas Layanan di RS Wijaya Kusuma Lumajang}

Berdasarkan hasil kuesioner yang disebarkan tentang kualitas layanan rumah sakit berdasarkan persepsi, harapan dan kepentingan masyarakat di Lumajang maka diperoleh urutan jenis layanan yang kemudian diambil prioritas yang harus diperbaiki agar Rumah Sakit Wijaya Kusuma Lumajang dapat memberikan layanan yang optimal. Prioritas perbaikan kualitas layanan pada Rumah Sakit Wijaya Kusuma Lumajang terdiri dari : (1) kelengkapan peralatan pemeriksaan, besarnya biaya pengobatan, dan (3) kejelasan informasi tindak lanjut hasil pemeriksaan.

Kelengkapan peralatan pemeriksaan, diketahui menjadi gap tertinggi bagi masyarakat yang menggunakan layanan 
kesehatan di rumah sakit ini.Masyarakat beranggapan bahwa rumah sakit ini mrmiliki kekurangan peralatan pemeriksaan kesehatan sehingga masyarakat yang dating ke rumah sakit ini tidak bisa mendapatkan pemeriksaan yang lengkap.Untuk mendapatkan pemeriksaan yang lengkap mereka harus dirujuk pada rumah sakit besar di Lumajang dan daerah di luar Lumajang.Besarnya biaya berobat di rumah sakit ini diketahui menjadi keluhan yang tinggi bagi masyarakat.Hal ini dapat dimaklumi mengingat rumah sakit ini merupakan salah satu rumah sakit swasta sehingga biaya pengobatan bagi sebagian masyarakat cukup memberatkan. Masyarakat juga beranggapan bahwa pihak rumah sakit kurang memberikan informasi yang jelas untuk tindak lanjut hasil pemeriksaan sehingga masyarakat harus bertanya lebih detail setelah pemeriksaan dilakukan.

Atas kondisi ini, maka disarankan kepada pihak Rumah Sakit Bhayangkara Lumajang untuk melakukan perbaikan sesuai urutan prioritas yang dikehendaki masyarakat terutama 3 (tiga) prioritas yang menimbulkan kesenjangan atau gap yang cukup tinggi berdasarkan persepsi, harapan dan kepentingan masyarakat, yaitu dengan melengkapi peralatan pemeriksaan, mempertimbangkan kembali tentang besarnya biaya pengobatan, membekali dan meningkatkan kemampuan petugas kesehatan agar mampu memberikan informasi yang jelas bagi masyarakat dalam menindaklanjuti hasil pemeriksaan. Namun demikian berdasarkan urutan prioritas tersebut, dapat diketahui bahwa rumah sakit ini memiliki keunggulan yaitu kesabaran petugas dalam mendengarlan keluhan pasien memiliki gap terkecil sehingga dapat diartikan bahwa masyarakat puas dengan kesabaran petugas di rumah sakit ini dalam mendengarkan keluhan mereka.

\section{Prioritas Perbaikan Kualitas Layanan di RS Islam Lumajang}

Berdasarkan hasil kuesioner yang disebarkan tentang kualitas layanan rumah sakit berdasarkan persepsi, harapan dan kepentingan masyarakat di Lumajang maka diperoleh urutan jenis layanan yang kemudian diambil prioritas yang harus diperbaiki agar Rumah Sakit Islam Lumajang dapat memberikan layanan yang optimal. Prioritas perbaikan kualitas layanan pada
Rumah Sakit Islam Lumajang terdiri dari : (1) kemampuan petugas menjelaskan hasil pemeriksaan, $\quad$ (2) kejelasan petugas dalam informasi biaya pemeriksaan, dan (3) lamanya waktu pelayanan petugas apotik.

Kemampuan petugas dalam menjelaskan hasil pemeriksaan masih dianggap masyarakat kurang optimal sehingga masyarakat tidak bisa memahami hasil pemeriksaan atas kesehatan mereka dengan baik. Kejelasan informasi biaya pemeriksaan di rumah sakit ini juga kurang bisa diterima dengan baik oleh masyarakat sehingga menimbulkan kesulitan bagi mereka untuk mempersiapkan biaya pengobatan atas pelayanan pemeriksaan kesehatan yang diterima. Lamanya petugas dalam memberikan pelayanan di apotik juga menjadi keluhan utama masyarakat dimana masyarakat dalam kondisi kesehatan yang kurang baik tentu akan sangat mengharapkan pelayanan obat-obatan di apotik rumah sakit ini bisa dilakukan dengan cepat dan tepat.

Atas kondisi ini, maka disarankan kepada pihak Rumah Sakit Islam Lumajang untuk melakukan perbaikan sesuai urutan prioritas yang dikehendaki masyarakat terutama 3 (tiga) prioritas yang menimbulkan kesenjangan atau gap yang cukup tinggi berdasarkan persepsi, harapan dan kepentingan masyarakat, yaitu dengan meningkatkan kemampuan petugas dalam menjelaskan hasil pemeriksaan, memberikan perincian biaya standar atas semua layanan di rumah sakit ini sehingga masyarakat dapat mengetahui dan mempersiapkan dana bagi pengobatan mereka, dan mempersingkat waktu pelayanan petugas di bagian apotik tetapi dengan tetap memperhatikan prinsip kehati-hatian dan ketelitian. Namun demikian berdasarkan urutan prioritas tersebut, dapat diketahui bahwa rumah sakit ini memiliki keunggulan yaitu penyampaian keluhan pasien ke rumah sakit memiliki gap terkecil sehingga dapat diartikan bahwa masyarakat puas dengan kemampuan rumah sakit ini dalam menanggapi keluhan pasien.

\section{KESIMPULAN}

Berdasarkan hasil kuesioner yang disebarkan tentang kualitas layanan rumah sakit berdasarkan persepsi, harapan dan kepentingan masyarakat di Lumajang maka diperoleh urutan jenis layanan yang berbeda 
di setiap rumah sakit di Lumajang. Prioritas perbaikan kualitas layanan pada RSUD Dr. Haryoto Lumajang terdiri dari kemampuan dan kecekatan hadapi keluhan pasien, keramahan petugas, dan ketrampilan dan keahlian petugas. Prioritas perbaikan kualitas layanan pada Rumah Sakit Bhayangkara Lumajang terdiri dari ketepatan waktu buka loket pelayanan, kesabaran petugas mendengarkan keluhan pasien, dan lamanya waktu pelayanan petugas loket. Prioritas perbaikan kualitas layanan pada Rumah Sakit Wijaya Kusuma Lumajang terdiri dari kelengkapan peralatan pemeriksaan, besarnya biaya pengobatan, dan kejelasan informasi tindak lanjut hasil pemeriksaan. Prioritas perbaikan kualitas layanan pada Rumah Sakit Islam Lumajang terdiri dari kemampuan petugas menjelaskan hasil pemeriksaan, kejelasan petugas dalam informasi biaya pemeriksaan, dan lamanya waktu pelayanan petugas apotik. Disarankan kepada pihak pengelola rumah sakit untuk dapat meningkatkan kualitas pelayanan agar tidak terjadi kesenjangan gap yang terlalu tinggi antara perepsi, harapan dan kepentingan masyarakat pengguna jasa rumah sakit.

\section{DAFTAR PUSTAKA}

Alma. B 2005. Manajemen Pemasaran dan Pemasaran Jasa. Edisi Revisi. CV. Alfabeta. Bandung.

Asih. Endang Widuri. 2014. Implementasi Six Sigma Pada Industri Jasa Untuk Peningkatan Kepuasan PelangganKoperasi Simpan Pinjam. Prosiding Seminar Nasional Aplikasi Sains dan Teknologi. Yogjakarta. ISSN: 1979-911X.

Bahia, Kamilia \& Jacques Nantel. 2000. A Reliable and Valid Measurement Scale of The Perceived Service Quality of Banks. International Jurnal of Bank Marketing. 18/2. halaman 84-91.

Doyle, Charles. 2013. Kamus Pemasaran. Edisi I. PT. Indeks. Indonesia.
Iriani. Yani. 2011. Usulan Peningkatan Kualitas Pelayanan Pelanggan Dengan Menggunakan Integrasi Model Servqual, Lean dan Six Sigma. Prosiding Seminar Nasional Teknik dan Manajemen Industri. Bandung. ISBN : 978979-796-189-3.

Kotler.Philip.2002. Manajemen Pemasaran di Indonesia : Analisis, Perencanaan, Implementasi dan Pengendalian. Salemba Empat. Jakarta.

\section{Marketing Management. $11^{\text {th }}$ Edition.Prentice Hall.Inc.New Jersey.}

Kotler. Philip dan Lane Keller. Kevin. 2007. Manajemen Pemasaranedisi 12 jilid 2. PT. Macanan Jaya cemerlang.

Nugroho. Anton. dan Yohanes. 2011. It's Easy Olah Data Dengan SPSS. Skripta Media Creative.Yogyakarta.

Parasuraman.Valarie A. Z. and Berry. 2002. Delivering Service Quality. Mc Milan. New York.

Rangkuti. Freddy. 2002. Measuring Customer Satisfaction. Gramedia Pustaka Utama.

Ricky. 2014. Upaya Peningkatan Kualitas Layanan Dengan Pendekatan Lean Sigma Pada Bank Papua Jayapura. Jurnal Ilmiah Calyptra. Vol 3 No 1. Universitas Surabaya. Surabaya.

Santoso. Haryo. 2006. Meningkatkan Kualitas Layanan Industri Jasa Melalui Pendekatan Integrasi Metode Servqual atau Servqual QFD._J@ti Universitas Diponegoro. Vol 1 No 1. Semarang.

Tjiptono. Fandi dan Chandra. Gregorius. 2011. Service, Quality \& 
Ato'illah, Implementasi Lean Six

Satisfication. CV. Andi Offset. Yogjakarta.

Thamrin. Francis. 2012. Manajemen Pemasaran. PT.Raja Grafindo Persada, Jakarta.

Wisnubroto. Petrus dan Anggoro. Theo. 2012. Analisis Kualitas Pelayanan Jasa Dengan Methode Six Sigma Pada Hotel Malioboro Inn Yogjakarta. Prosiding Seminar
Nasional Aplikais Sains dan Teknologi Periode III. Yogjakarta. ISSN:1979-911X.

Zeithaml. Valarie A. and Bitner. Mary Jo. 2002. Service Marketin.McGraw Hill Inc. Int'l Edition. New York.

Wahyuni, Hana Catur, dkk. 2015. Pengendalian Kualitas. Graha Ilmu. Yogjakarta. 